\title{
PEMBANGUNAN MODUL DOKUMENTASI APLIKASI POINT OF SALE ODOO BERBASIS WEB DI PT BELANT PERSADA
}

\section{(The Development of Application Documentation Module Point of Sale Odoo Based on Web at PT Belant Persada)}

\author{
PUJI DWI GUSTIANI ${ }^{1}$, RINA TRISMININGSIH ${ }^{2}$, LUFTY ABDILLAH ${ }^{3}$ \\ 1 Sekolah Vokasi Institut Pertanian Bogor, Jl. Kumbang No. 14, Babakan, Bogor \\ ${ }^{2}$ Sekolah Vokasi Institut Pertanian Bogor, Jl. Kumbang No. 14, Babakan, Bogor \\ ${ }^{3}$ Grand Galaxy City, Ruko Sentra Komersial 3 No. 32, Jaka Setia, Bekasi \\ Email : gustianipuji@gmail.com
}

\begin{abstract}
Odoo is an open source ERP application where there are various business programs such as Sales, Point of Sale, CRM, Human Resources, Finance and Accounting and others. One application module developed by Odoo is Point of Sale. Point of sale (POS) is a system that can help the transaction process in a business that is engaged in sales such as supermarkets, restaurants, clothing stores and so others. The use of the Odoo POS application among Indonesian people still sounds not familiar because of the lack of information related to the use of the Odoo POS application. Documentation from the Odoo POS application is available on the Odoo websiteHowever, the documentation does not yet have the function to download documentation files and has not been displayed visually in video format. From this, there is a need for documentation using the Odoo POS application that can download documentation files and display documentation visually in video format to distinguish between the original POS Odoo application documentation module and the Odoo POS application documentation module that the author made. For this reason, was built Application Documentation Module Point of Sale Odoo Based on Web at Pt Belant Persada. The Odoo POS application documentation module contains documentation about the use of the POS Odoo application for retail and restaurant fields and this documentation can be downloaded freely in PDF format and displays the documentation visually in video formatThe method used in the development of the Odoo POS application documentation module is the prototype method. This method has five stages is Communication, Quick Plan, Modeling Quick Design, Construction of Prototype, and Deployment, Delivery, \& Feedback.

Key words: Documentation, prototype methods, Odoo, POS
\end{abstract}

\section{ABSTRAK}

Odoo adalah aplikasi ERP bersifat open source yang di dalamnya terdapat berbagai program bisnis seperti Sales, Point of Sale, CRM, Human Resource, Finance and Accounting dan lain sebagainya. Salah satu modul aplikasi yang dikembangkan oleh Odoo yaitu Point of Sale. Point of sale (POS) merupakan sebuah sistem yang dapat membantu proses transaksi pada suatu bisnis yang 
bergerak di bidang penjualan seperti toko swalayan, restoran, toko baju dan lain sebagainya. Penggunaan aplikasi POS Odoo di kalangan masyarakat Indonesia masih terdengar asing karena minimnya informasi terkait penggunaan aplikasi POS Odoo. Dokumentasi dari aplikasi POS Odoo sudah ada di website Odoo. Namun, dokumentasi tersebut belum mempunyai fungsi untuk mengunduh file dokumentasi dan belum ditampilkan secara visual dalam format video. Dari hal tersebut, perlu adanya suatu dokumentasi penggunaan aplikasi POS Odoo yang dapat mengunduh file dokumentasi dan menampilkan dokumentasi secara visual dalam format video untuk membedakan antara modul dokumentasi aplikasi POS Odoo yang asli dengan modul dokumentasi aplikasi POS Odoo yang penulis buat. Untuk itu, dibangunlah Modul Dokumentasi Aplikasi Point of Sale Odoo Berbasis Web di PT Belant Persada. Modul dokumentasi aplikasi POS Odoo berisi tentang dokumentasi penggunaan aplikasi POS Odoo untuk bidang retail dan restaurant serta dokumentasi ini dapat diunduh dalam format PDF secara bebas dan menampilkan dokumentasi secara visual dalam format video. Metode yang digunakan dalam pembangunan modul dokumentasi aplikasi POS Odoo adalah metode prototipe. Metode ini mempunyai lima tahapan yaitu Communication, Quick Plan, Modelling Quick Design, Construction of Prototype, dan Deployment, Delivery, \& Feedback.

Kata kunci : Dokumentasi, metode prototipe, Odoo, POS.

\section{PENDAHULUAN}

\subsection{Latar Belakang}

Enterprise Resource Planning (ERP) merupakan sebuah sistem informasi yang berperan untuk mengintegrasikan dan mengotomisasikan proses bisnis pada perusahaan dalam berbagai aspek, mulai dari aspek operasional, produksi sampai distribusi (Hardjono 2017). Penggunaan ERP menjadikan semua sistem di dalam suatu perusahaan menjadi satu sistem yang terintegrasi dengan satu database sehingga menjadi lebih mudah dalam berbagi data.

Odoo adalah aplikasi ERP bersifat open source yang di dalamnya terdapat berbagai program bisnis seperti Sales, Point of Sale, CRM, Human Resource, Finance and Accounting, dan lain sebagainya. Odoo menggunakan bahasa pemrograman Phtyon, XML, dan Javascript serta PostgreeSQL sebagai database management system (Lestari 2017). Dengan menggunakan aplikasi Odoo suatu bisnis tidak perlu mengeluarkan biaya yang tinggi dalam pembuatan aplikasi ERP. Aplikasi Odoo dapat diunduh secara gratis dan mempunyai modul yang lengkap serta saling terintegrasi.

Salah satu modul aplikasi yang dikembangkan oleh Odoo yaitu Point of Sale. Point of sale (POS) merupakan sebuah sistem yang dapat membantu proses transaksi pada suatu bisnis yang bergerak di bidang penjualan seperti toko swalayan, restoran, toko baju, dan lain sebagainya. Manfaat POS yaitu memudahkan proses pengecekan barang yang tersedia, pengambilan keputusan dan dapat meningkatkan kualitas pelayanan dalam bisnis (Sani et al. 2018). Penggunaan aplikasi POS Odoo di kalangan masyarakat Indonesia masih terdengar asing. Banyak masyarakat yang tidak mengetahui penggunaan aplikasi 
ini karena minimnya informasi terkait penggunaan aplikasi POS Odoo. Dokumentasi dari aplikasi POS Odoo sudah ada di website Odoo. Namun, dokumentasi tersebut belum mempunyai fungsi untuk mengunduh file dokumentasi dan belum ditampilkan secara visual dalam format video.

Dari hal tersebut, perlu adanya suatu dokumentasi penggunaan aplikasi POS Odoo yang dapat mengunduh file dokumentasi dan menampilkan dokumentasi secara visual dalam format video untuk membedakan antara dokumentasi Odoo asli dengan modul dokumentasi yang penulis buat. Untuk itu, dibangunlah Modul Dokumentasi Aplikasi Point of Sale Odoo Berbasis Web di PT Belant Persada untuk masyarakat yang ingin belajar mengenai penggunaan aplikasi POS Odoo. Modul dokumentasi aplikasi POS Odoo berisi tentang dokumentasi penggunaan aplikasi POS Odoo untuk bidang retail dan restaurant serta dokumentasi ini dapat diunduh dalam format PDF secara bebas dan menampilkan dokumentasi secara visual dalam format video. Dengan adanya modul dokumentasi ini, diharapkan dapat membantu masyarakat dalam penggunaan aplikasi POS Odoo.

\subsection{Tujuan}

Tujuan penulis dalam pembuatan tugas akhir ini yaitu membangun modul dokumentasi penggunaan aplikasi POS Odoo untuk masyarakat yang ingin belajar mengenai penggunaan aplikasi ini, khususnya di bidang retail dan restaurant.

\section{METODE PENELITIAN}

Dalam pembuatan sistem diperlukan sebuah metode untuk menentukan alur dari sistem yang dikembangkan dan mengidentifikasi kebutuhan fungsional sistem. Metode yang digunakan untuk Pembangunan Modul Dokumentasi Aplikasi Point of Sale Odoo Berbasis Web di PT Belant Persada yaitu metode prototipe. Menurut Pressman (2010), pembuatan sistem dengan metode prototipe mempunyai lima tahapan yaitu Komunikasi (Communication), Perencanaan Secara Cepat (Quick Plan), Pemodelan Rancangan Secara Cepat (Modelling Quick Design), Pembentukan Prototipe (Construction of Prototype), dan Penyerahan Sistem dan Umpan Balik (Deployment, Delivery, \& Feedback). Alur metode prototipe dapat dilihat pada Gambar 1 . 




Gambar 1 Alur metode prototipe

\subsection{Komunikasi (Communication)}

Tahap pertama adalah komunikasi. Pengembang dan pelanggan melakukan pertemuan untuk mendefinisikan tujuan keseluruhan sistem dan mengidentifikasi kebutuhan apa pun yang diketahui untuk dikembangkan (Pressman 2010). Tahap komunikasi dilakukan dengan teknik wawancara antara penulis dengan pembimbing lapang yang merupakan salah satu staf di Divisi ERP Solution dengan jabatan sebagai ERP Technical Consultant. Tujuan wawancara yaitu untuk mengidentifikasi kebutuhan fungsional dalam pembangunan modul dokumentasi aplikasi POS Odoo. Setelah melakukan wawancara dengan pembimbing lapang, dihasilkan beberapa informasi terkait kebutuhan sistem dalam membangun modul dokumentasi aplikasi POS Odoo berbasis web.

\subsection{Perencanaan Secara Cepat (Quick Plan)}

Tahap kedua adalah perencanaan secara cepat. Tahap ini dilakukan untuk menjelaskan lebih rinci mengenai rencana dari sistem yang dibuat. Pada tahap ini juga dilakukan analisis pengguna yang dibutuhkan oleh sistem. Pengguna dalam modul dokumentasi aplikasi POS Odoo ini adalah user atau masyarakat umum dan admin yang merupakan salah satu pegawai di Divisi ERP Solution. User berperan sebagai pengunjung dari modul dokumentasi aplikasi POS Odoo, sedangkan admin berperan sebagai pengelola data dokumentasi pada sistem admin. Berdasarkan hasil wawancara di tahap komunikasi, pada tahap ini diperoleh beberapa fitur yang dibutuhkan untuk pembangunan modul dokumentasi aplikasi POS Odoo .

\subsection{Pemodelan Rancangan Secara Cepat (Modelling Quick Design)}

Tahap ketiga adalah pemodelan rancangan secaran cepat. Pemodelan rancangan secara cepat berfokus pada representasi semua aspek perangkat lunak yang akan terlihat oleh pengguna (misalnya rancangan antarmuka pengguna atau format tampilan) (Pressman 2010). Pemodelan rancangan secara cepat mengarah pada pembangunan prototipe. Proses pemodelan rancangan 
secara cepat pada modul dokumentasi aplikasi POS Odoo dilakukan dengan pembuatan Unified Modelling Languange (UML) yang berupa perancangan use case diagram, class diagram, dan activity diagram, serta perancangan antarmuka. Pada tahap ini menghasilkan alur kerja dari modul dokumentasi aplikasi POS Odoo dan rancangan prototipe dengan membuat desain antarmuka untuk modul dokumentasi aplikasi POS Odoo.

\subsection{Pembentukan Prototipe (Construction of Prototype)}

Tahap keempat adalah pembentukan prototipe. Pada tahap ini pengembang mulai membangun sistem yang sudah dijabarkan dari tahapan sebelumnya. Pengembang mulai menerjemahkan desain yang telah dibuat menggunakan bahasa pemrograman. Dalam pembuatan modul dokumentasi aplikasi POS Odoo menggunakan bahasa pemrograman PHP dengan framework Codelgniter. Pada tahap ini menghasilkan modul dokumentasi aplikasi POS Odoo berdasarkan rancangan prototipe yang sudah dibuat.

\subsection{Penyerahan Sistem dan Umpan Balik (Deployment, Delivery, And Feedback)}

Tahap terakhir adalah penyerahan sistem dan umpan balik. Prototipe yang sudah diimplementasikan, diserahkan kepada pelanggan dan dilakukan pengujian. Tahap Pembangunan Modul Dokumentasi Aplikasi POS Odoo berbasis Web di PT Belant Persada telah selesai dibangun dan diserahkan ke Bapak Lufty Abdillah selaku pembimbing lapang yang merupakan salah satu staf di Divisi ERP Solution. Modul dokumentasi aplikasi POS Odoo telah dilakukan pengujian sistem menggunakan Black box testing. Black box testing adalah pengujian sistem yang dilakukan dengan memasukan beberapa kondisi tertentu yang sepenuhnya akan menjalankan semua kebutuhan fungsional dari sistem (Satzinger et al.2012). Dalam pengujian sistem diperlukan sebuah skenario pengujian yang bertujuan untuk mengetahui fungsional apa saja yang sudah berhasil dibuat.

\section{HASIL DAN PEMBAHASAN}

Pada bagian ini membahas secara rinci mengenai sistem yang diimplementasikan dengan menggunakan metode prototipe. Pembangunan modul dokumentasi aplikasi POS Odoo terdapat lima tahapan yaitu Komunikasi (Communication), Perencanaan Secara Cepat (Quick Plan), Pemodelan Rancangan Secara Cepat (Modelling Quick Design), Pembentukan Prototipe (Construction of Prototype), dan Penyerahan Sistem dan Umpan Balik (Deployment, Delivery, \& Feedback).

\subsection{Komunikasi}

Tahap pertama adalah komunikasi. Tahap komunikasi dilakukan dengan teknik wawancara antara penulis dengan pembimbing lapang yang merupakan salah satu staf di Divisi ERP Solution dengan jabatan sebagai ERP Technical Consultant. Tujuan wawancara yaitu untuk mengindentifikasi kebutuhan fungsional dalam pembangunan modul dokumentasi aplikasi POS Odoo. Point yang didapat dari wawancara ialah sebagai berikut: 
1. Membuat sebuah modul dokumentasi yang berisi tentang dokumentasi aplikasi POS Odoo dengan sasaran untuk masyarakat yang ingin tau atau belajar terkait penggunaan aplikasi POS Odoo.

2. User dapat melihat dokumentasi aplikasi POS Odoo dalam format video.

3. User dapat menguduh file dokumentasi aplikasi POS Odoo dalam format PDF.

4. Admin dapat mengelola data dokumentasi.

5. Tampilan antarmuka untuk halaman dokumentasi kurang lebih mirip dengan tampilan antarmuka pada halaman dokumentasi website Odoo. Antarmuka halaman dokumentasi Point of Sale pada website Odoo dapat dilihat pada Gambar 2.

Gambar 2 Antarmuka halaman dokumentasi Point of Sale pada website Odoo

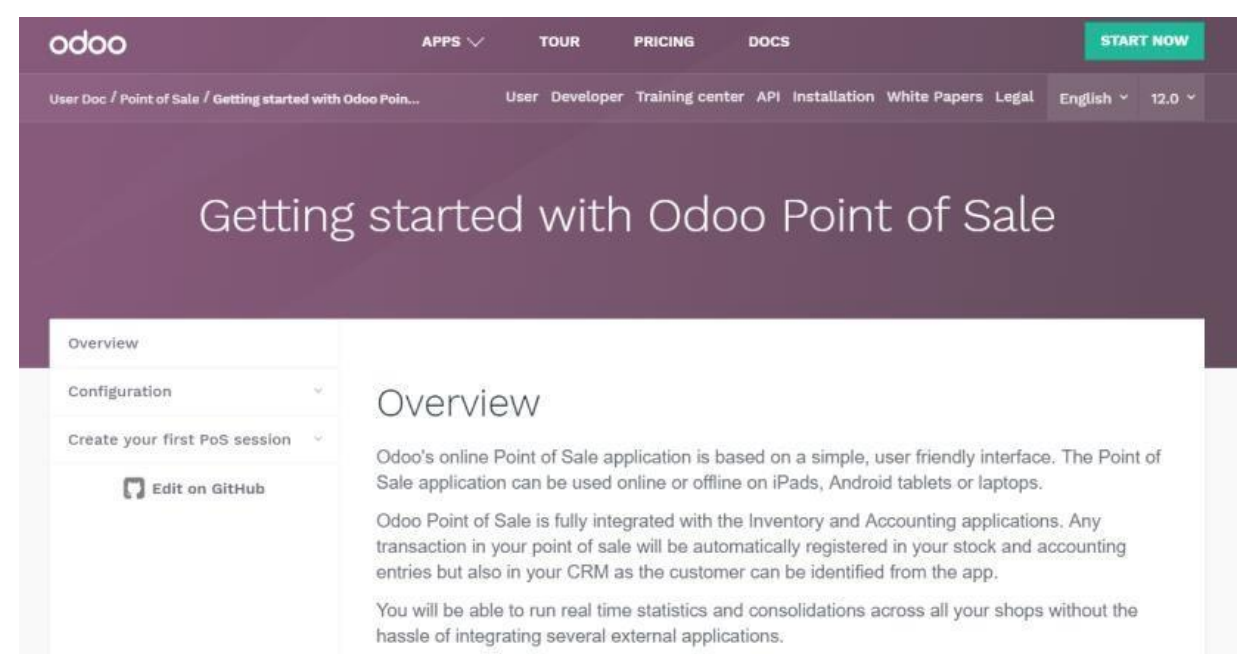

6. Proses bisnis user dalam melihat dokumentasi aplikasi POS Odoo. Pada proses bisnis ini, user dapat mengklik fitur dokumentasi, kemudian menampilkan beberapa kategori yang terdiri dari subkategori. Jika pilih salah satu subkategori dari kategori tertentu, maka menampilkan isi dokumentasi sesusai dengan subkategori yang dipilih. Proses bisnis user dapat dilihat pada Gambar 3. 


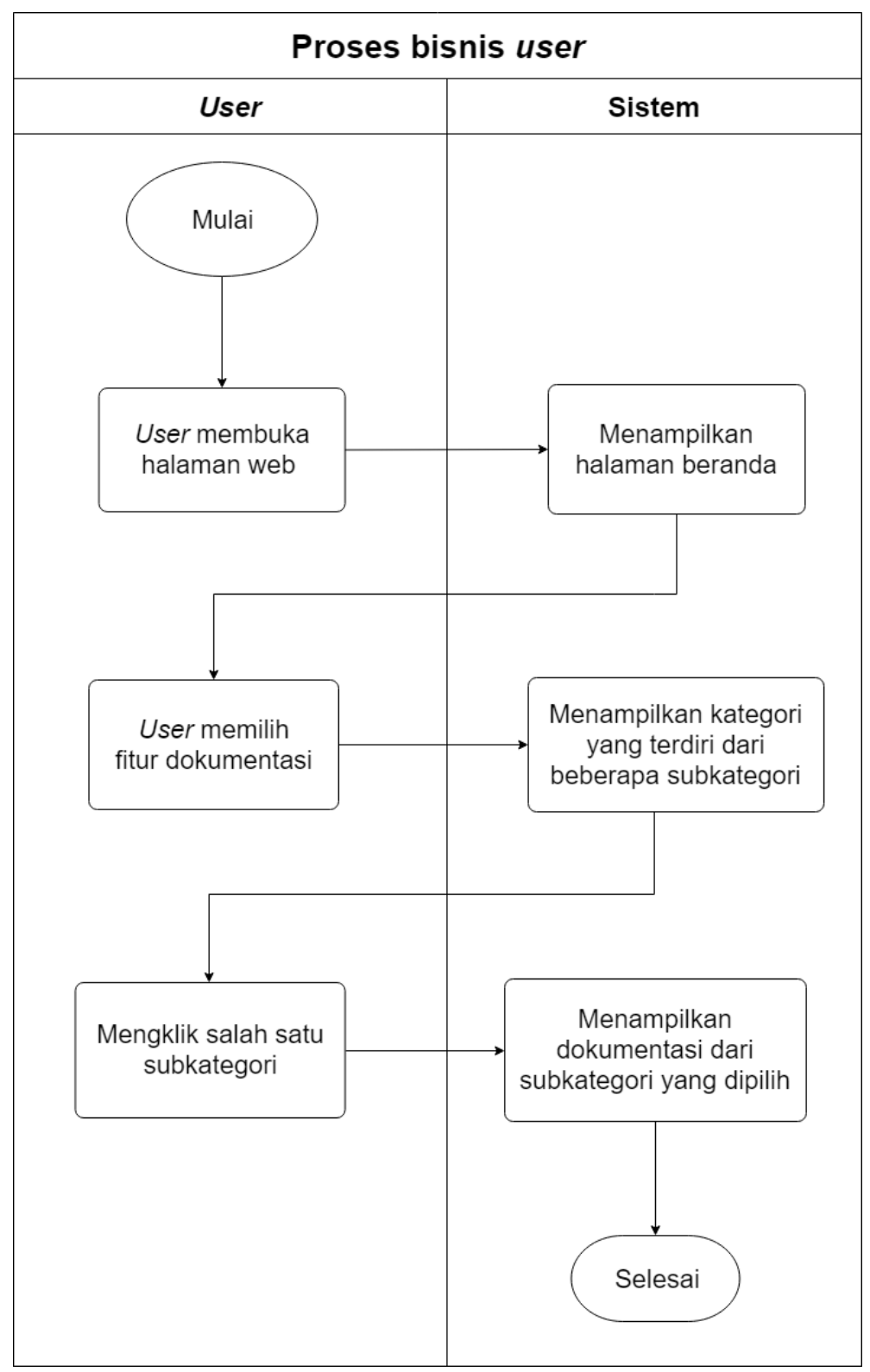

Gambar 3 Proses bisnis user

7. Proses bisnis admin dalam mengelola data dokumentasi. Pada proses bisnis ini, admin harus melakukan login sistem terlebih dahulu di sistem admin. Jika sudah login, admin dapat memulai melakukan pengelolaan data dokumentasi seperti menambah data, mengubah data, dan menghapus data. Data dokumentasi yang dikelola berupa data admin, kategori, subkategori, konten, dan video. Proses bisnis admin dapat dilihat pada Gambar 4. 


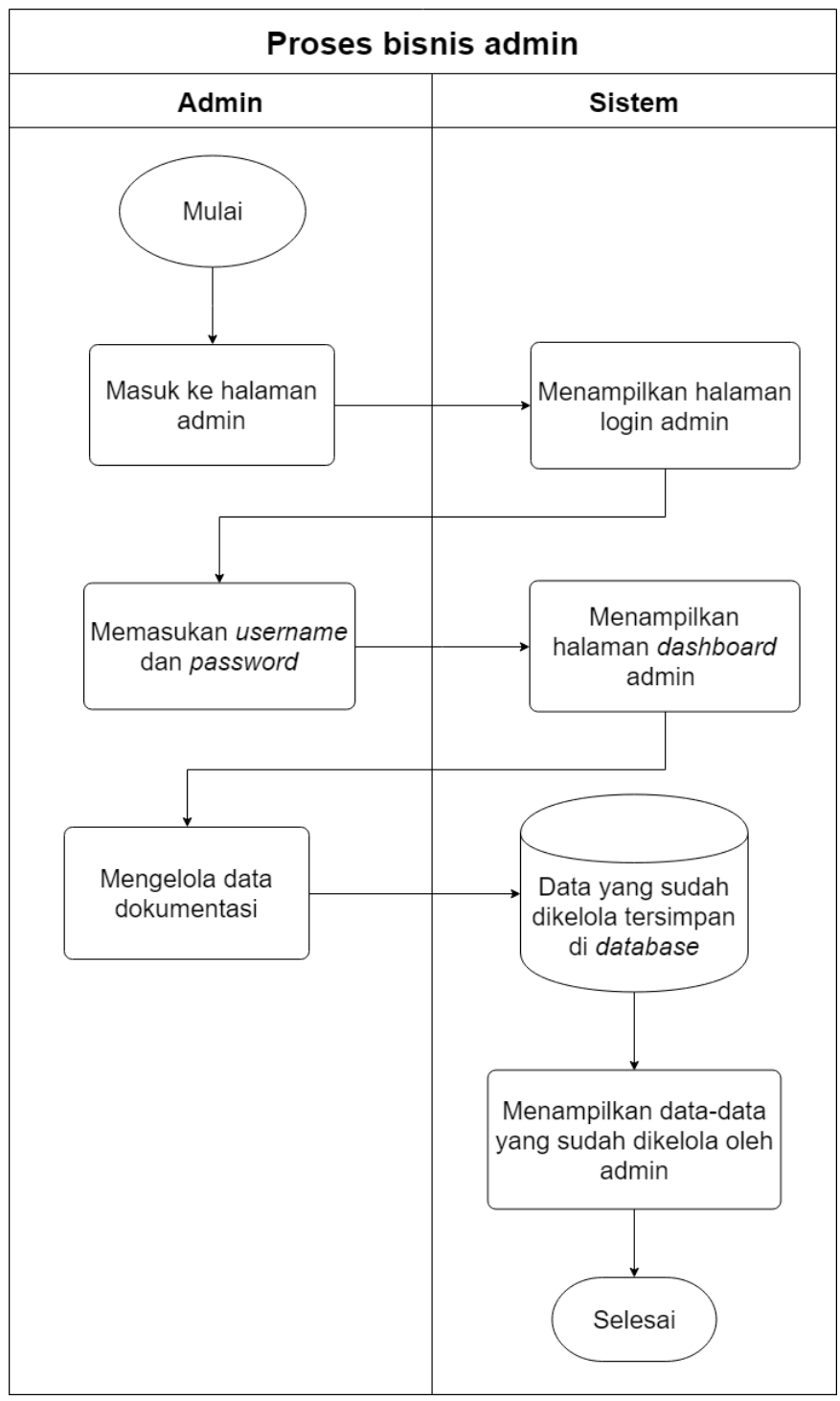

Gambar 4 Proses bisnis admin

\subsection{Perencanaan Secara Cepat}

Tahap kedua setelah komunikasi adalah perencanaan secara cepat. Tahap ini dilakukan untuk menjelaskan lebih rinci mengenai rencana dari sistem yang dibuat. Pada tahap ini juga dilakukan analisis pengguna yang dibutuhkan oleh sistem. Pengguna dalam modul dokumentasi aplikasi POS Odoo ini adalah user atau masyarakat umum dan admin merupakan salah satu pegawai di Divisi ERP Solution. User berperan sebagai pengunjung dari modul dokumentasi aplikasi POS Odoo, sedangkan admin berperan sebagai pengelola data dokumentasi pada sistem admin. Estimasi waktu dalam pembangunan modul dokumentasi aplikasi POS Odoo berbasis web adalah dua bulan. Perencanaan secara cepat menghasilkan kebutuhan informasi sistem.

\subsubsection{Kebutuhan Informasi Sistem}

Berdasarkan point yang didapat dari hasil wawancara dengan pembimbing lapang di PT Belant Persada diperoleh beberapa fitur yang dibutuhkan dalam pembangunan modul dokumentasi aplikasi POS Odoo yaitu: 
1. Menyediakan fitur admin berfungsi untuk admin mengelola data admin.

2. Menyediakan fitur kategori berfungsi untuk admin mengelola data kategori.

3. Menyediakan fitur subkategori berfungsi untuk admin mengelola data subkategori.

4. Menyediakan fitur konten berfungsi untuk admin mengelola data konten.

5. Menyediakan fitur unggah video berfungsi untuk admin mengelola data video.

6. Menyediakan fitur beranda berfungsi untuk user melihat web dokumentasi secara umum.

7. Menyediakan fitur dokumentasi berfungsi untuk user melihat dokumentasi dari aplikasi POS Odoo.

8. Menyediakan fungsi unduh berfungsi untuk user mengunduh file dokumentasi dalam format PDF.

\subsection{Pemodelan Rancangan Secara Cepat}

Tahap ketiga adalah pemodelan rancangan secara cepat. Proses pemodelan rancangan secara cepat dilakukan dengan pembuatan Unified Modelling Languange (UML) yang berupa perancangan use case diagram, class diagram, dan activity diagram, serta perancangan antarmuka.

\subsubsection{Perancangan Use Case Diagram}

Peracangan use case diagram berfungsi untuk mengetahui fungsi apa saja yang terdapat di dalam sistem. Use case diagram tidak menjelaskan secara rinci mengenai aktivitas yang dilakukan oleh aktor pada sistem. Setiap use case didokumentasikan dengan membuat use case description. Perancangan use case diagram untuk modul dokumentasi aplikasi POS Odoo dapat dilihat pada Gambar 5. Salah satu contoh use case description untuk modul dokumentasi yaitu use case description melihat dokumentasi dapat dilihat pada Tabel 1.

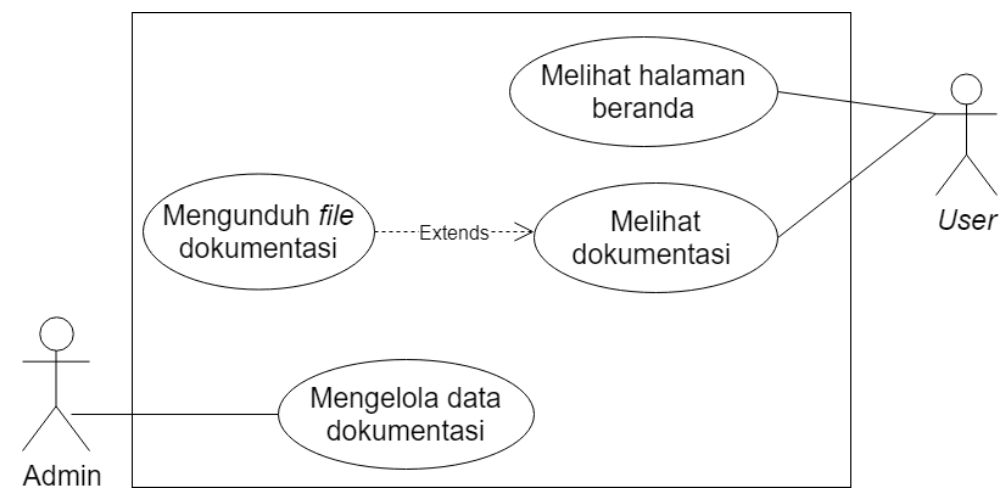

Gambar 5 Perancangan use case diagram untuk modul dokumentasi aplikasi POS Odoo

Tabel 1 Use case description melihat dokumentasi

\begin{tabular}{ccc}
\hline No & Use case & \multicolumn{1}{c}{ Deskripsi } \\
\hline Nama & $\begin{array}{l}\text { Melihat dokumentasi } \\
\text { User dapat melihat halaman dokumentasi yang } \\
\text { berisi dokumentasi serta video dokumentasi dari } \\
\text { setiap subkategori }\end{array}$ \\
\hline
\end{tabular}




\begin{tabular}{ll}
\hline No Use case & \multicolumn{1}{c}{ Deskripsi } \\
\hline & 1. Menampilkan halaman beranda \\
& 2. Memilih fitur dokumentasi \\
3liran utama & $\begin{array}{l}\text { 4. Menampilkan halaman dokumentasi } \\
\text { 4. Memilih salah satu subkategori untuk melihat } \\
\text { dokumentasi POS Odoo secara rinci }\end{array}$ \\
& 5. Menampilkan isi dokumentasi
\end{tabular}

Aliran alternatif

Kondisi akhir User keluar dari halaman web dokumentasi

Aliran alternatif

\subsubsection{Perancangan Activity Diagram}

Activity diagram berfungsi untuk menjelaskan alur kerja dari setiap use case pada sistem yang dibuat. Salah satu activity diagram dari modul dokumentasi aplikasi POS Odoo dapat dilihat pada Gambar 6 yang menunjukan activity diagram untuk melihat dokumentasi aplikasi POS Odoo.

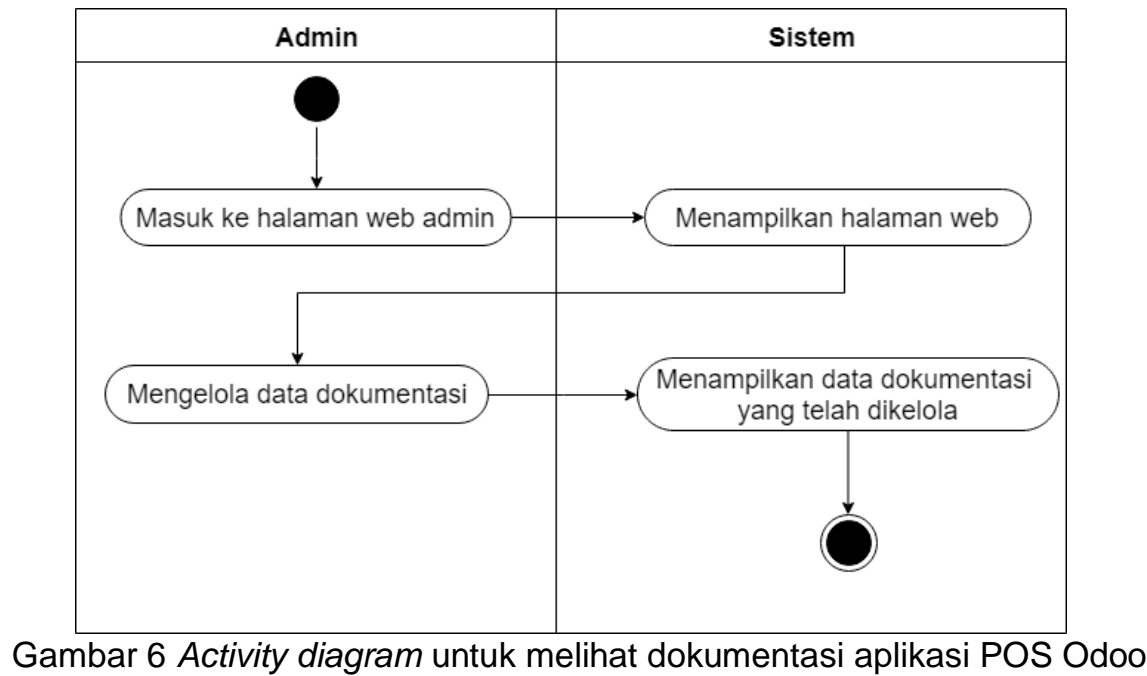

\subsubsection{Perancangan Class Diagram}

Perancangan class diagram berfungsi untuk menunjukan kelas objek pada suatu sistem. Class memiliki atribut dan metode atau operasi. Atribut merupakan variabel-variabel yang dimiliki oleh suatu kelas, sedangkan metode atau operasi adalah fungsi-fungsi yang dimiliki oleh suatu kelas. Perancangan class diagram untuk modul dokumentasi aplikasi POS Odoo memiliki 5 kelas yaitu kategori, subkategori, konten, unggah video, dan admin. Perancangan class diagram untuk modul dokumentasi aplikasi POS Odoo dapat dilihat pada Gambar 7. 


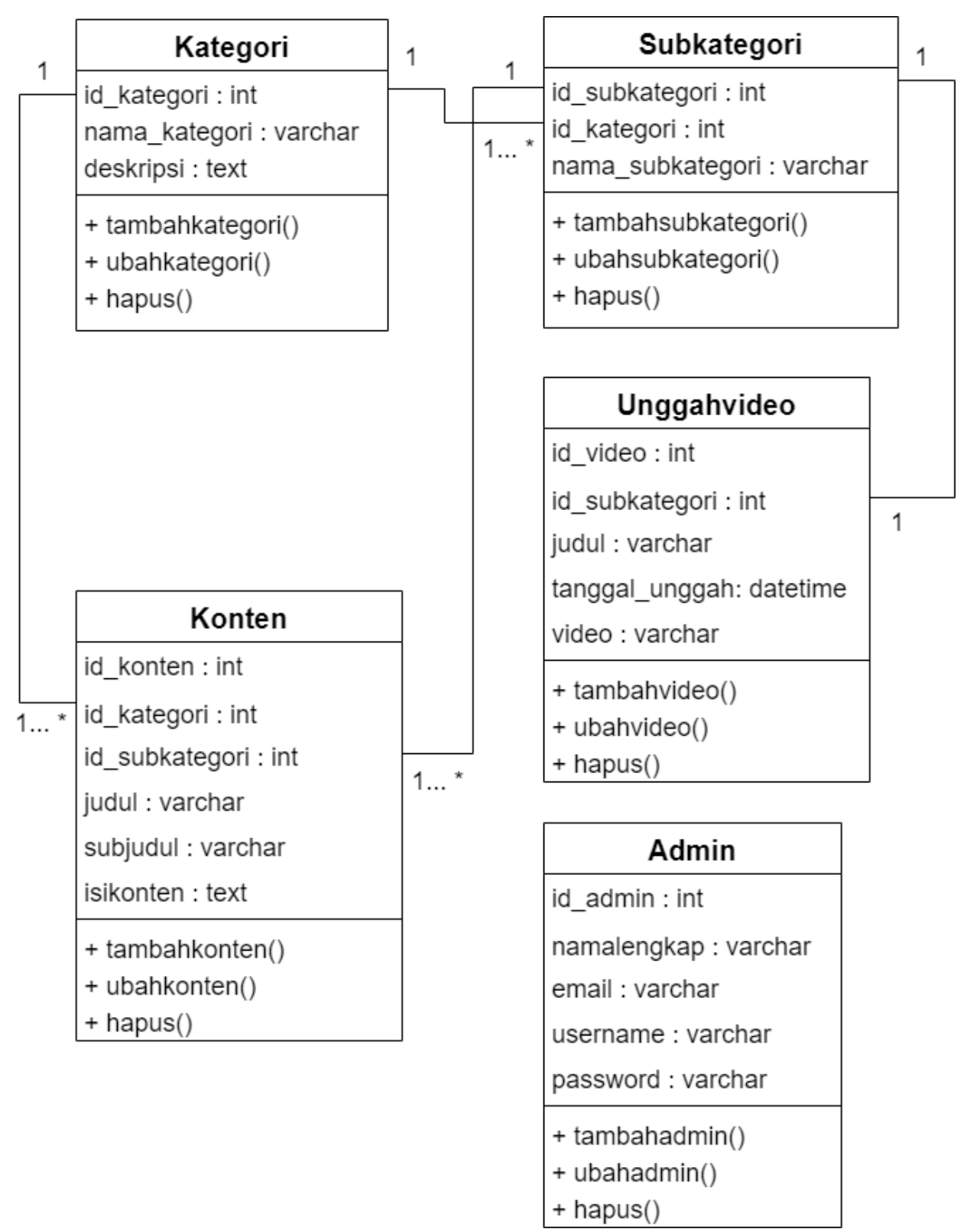

Gambar 7 Perancangan class diagram untuk modul dokumentasi aplikasi POS Odoo

\subsubsection{Peracangan Antarmuka}

Perancangan antarmuka dilakukan dengan membuat desain antarmuka yang berfungsi untuk memberikan gambaran mengenai tampilan sistem yang dibuat. Perancangan antarmuka pada modul dokumentasi aplikasi POS Odoo ini memiliki dua antarmuka yaitu antarmuka masukan dan antarmuka keluaran. Salah satu rancangan antarmuka masukan yaitu rancangan antarmuka masukan untuk menambah data konten dapat dilihat Gambar 8. Adapun salah satu rancangan antarmuka keluaran yaitu rancangan antarmuka keluaran untuk melihat data konten dapat dilihat pada Gambar 9. 


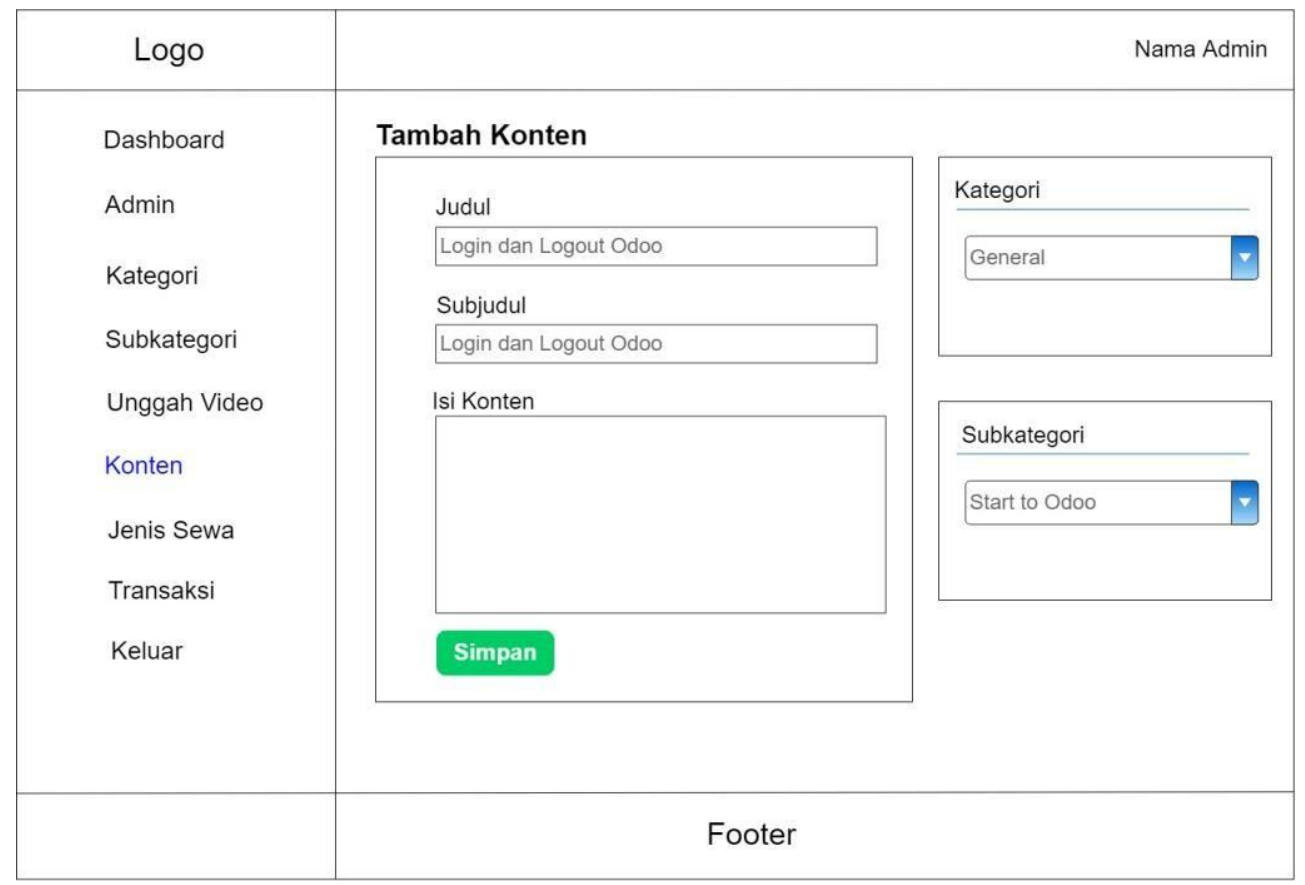

Gambar 8 Rancangan antarmuka masukan untuk menambah data konten

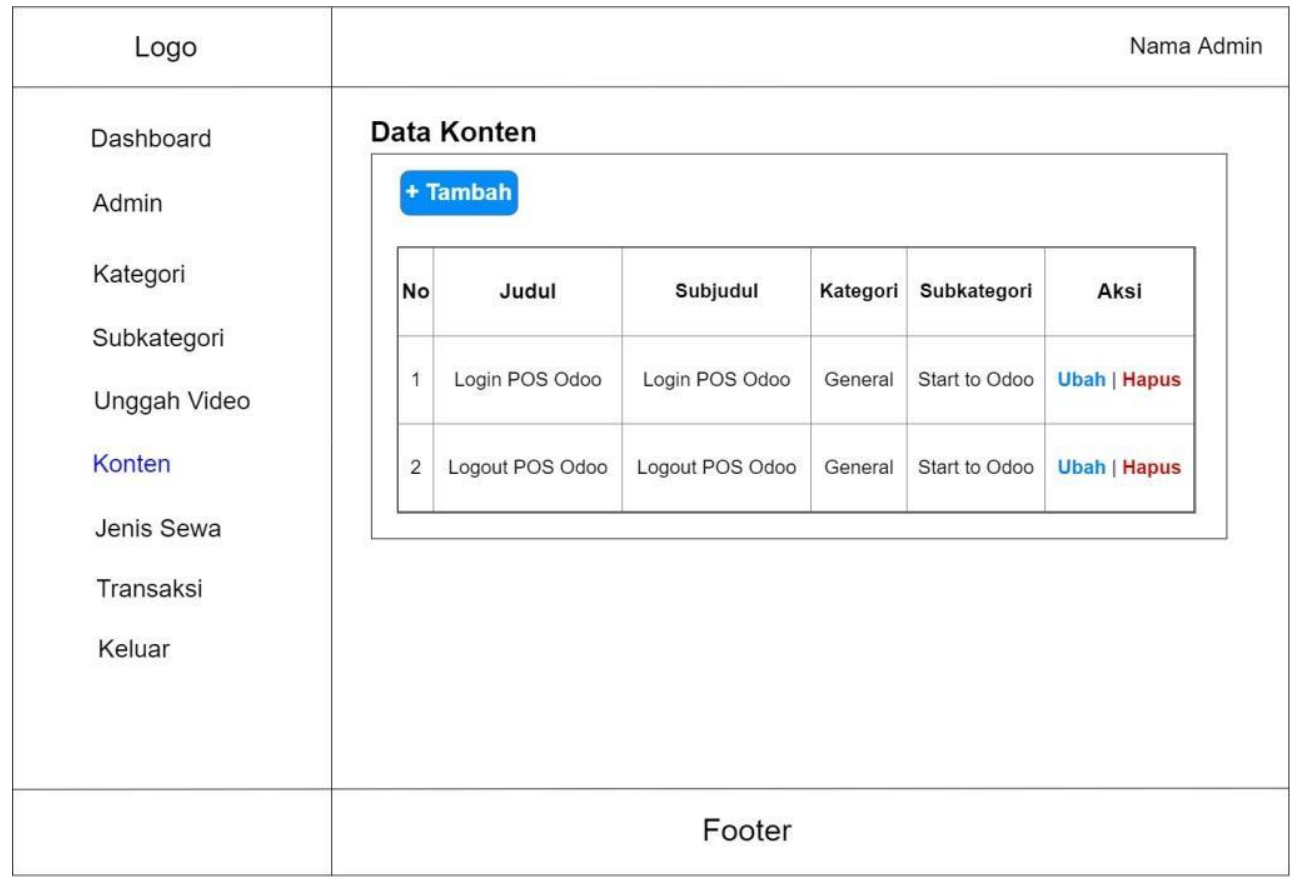

Gambar 9 Rancangan antarmuka keluaran untuk melihat data konten

\subsection{Pembentukan Prototipe}

Tahap keempat adalah pembentukan prototipe. Pembentukan prototipe merupakan tahapan untuk mengimplementasikan prototipe yang telah dibuat pada tahapan sebelumnya. Implementasi yang dilakukan antara lain implementasi database, implementasi proses dan implementasi antarmuka. 


\subsubsection{Perangkat Keras}

Dalam Pembangunan Modul Dokumentasi Aplikasi Point of Sale Odoo Berbasis Web di PT Belant Persada menggunakan perangkat keras laptop dengan spesifikasi sebagai berikut:

1 Processor AMD A4-5000 APU with Radeon (TM) HD Graphics $1.50 \mathrm{GHz}$

2 Memory RAM 4 GB

3 Kapasitas harddisk $200 \mathrm{~GB}$

4 Ukuran layar 14"

\subsubsection{Perangakat Lunak}

Dalam Pembangunan Modul Dokumentasi Aplikasi Point of Sale Odoo Berbasis Web di PT Belant Persada menggunakan perangkat lunak dengan spesifikasi sebagai berikut :

1 Sistem operasi : Windows 1064 -bit

2 DBMS : MySql

3 Text Editor: Sublime Text 3

4 Bahasa pemrograman:PHP

5 Web Browser: Google Chrome

6 Framework: Codelgniter

\subsubsection{Implementasi Database}

Berdasarkan perancangan class diagram yang sudah dibuat, class kemudian diimplementasikan dengan membuat sebuah database untuk pengelolaan data. Pada database ini terdapat lima tabel yaitu tabel admin, kategori, subkategori, konten, dan unggah video. Tampilan dari implementasi database untuk modul dokumentasi aplikasi POS Odoo dapat dilihat pada Gambar 10.

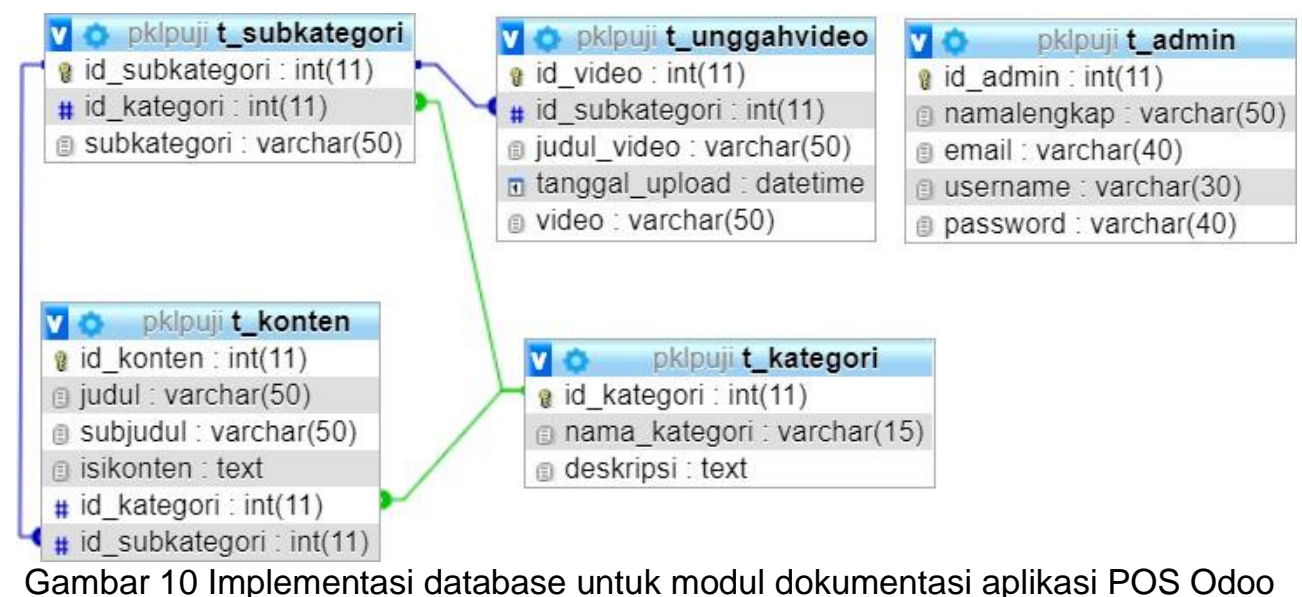

\subsubsection{Implementasi Antarmuka}

Implementasi antarmuka merupakan tahapan dalam mengimplementasikan antarmuka dari desain antarmuka yang sudah dibuat pada tahapan sebelumnya. Impelementasi antarmuka dari modul dokumentasi aplikasi POS Odoo memiliki dua antarmuka yaitu antarmuka masukan dan keluaran. Salah satu implementasi tampilan antarmuka masukan yaitu implementasi antarmuka masukan untuk 
menambah data konten dapat dilihat pada Gambar 11. Adapun salah satu implementasi tampilan antarmuka keluaran yaitu implementasi antarmuka keluaran untuk melihat data konten dapat dilihat pada Gambar 12.

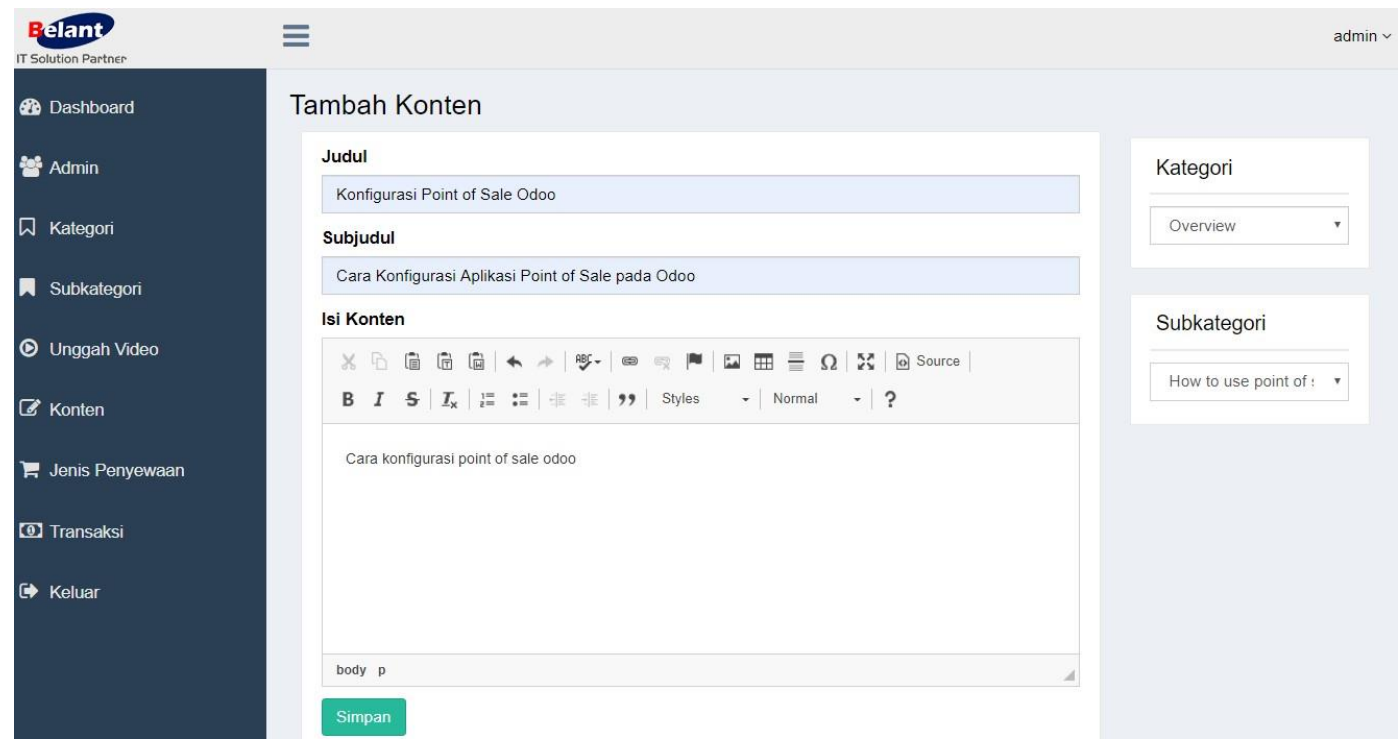

Gambar 11 Implementasi antarmuka masukan untuk menambah data konten

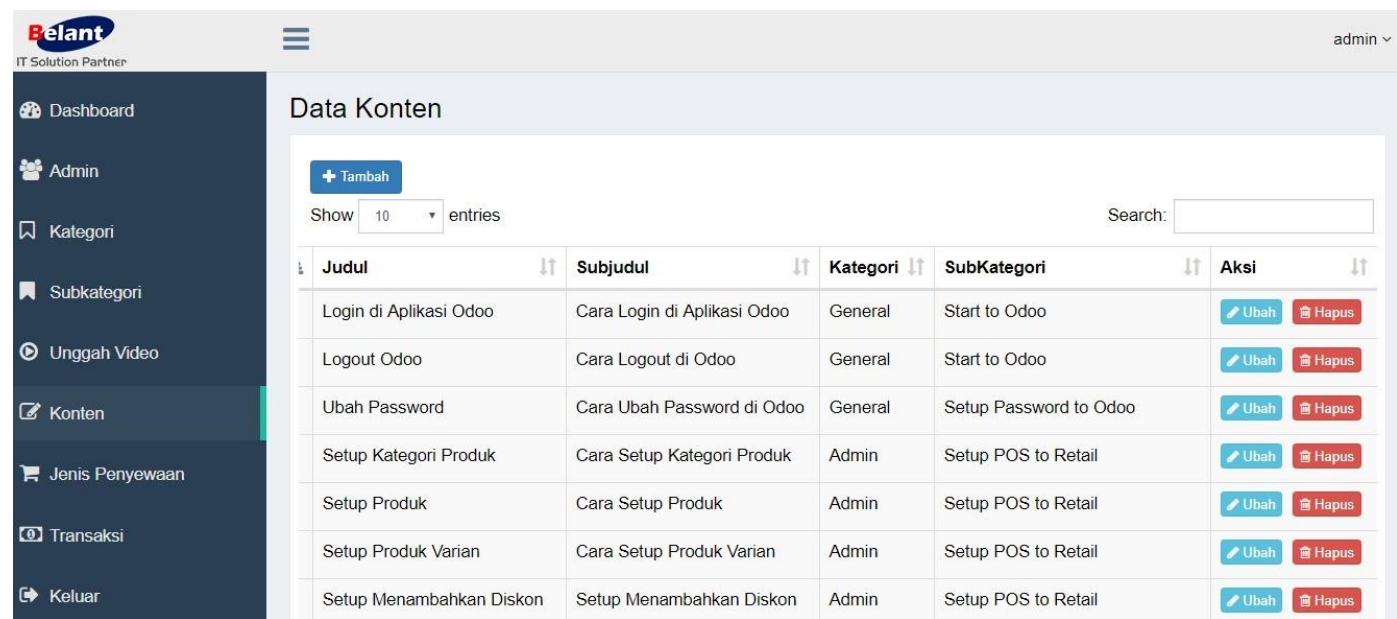

Gambar 12 Implementasi antarmuka keluaran untuk melihat data konten

\subsubsection{Implementasi Proses}

Implementasi proses merupakan proses pembuatan fungsi yang terdapat pada sistem. Pada tahapan ini terdapat potongan code program sistem yang dibuat. Implementasi proses pada Pembangunan Modul Dokumentasi Aplikasi POS Odoo Berbasis Web menggunakan bahasa pemrograman PHP dan framework Codelgniter versi 3.1.9 dengan konsep Model-View-Controller (MVC). Model yaitu merepresentasikan data pada sistem yang berhubungan dengan database untuk manipulasi data, View berfungsi untuk menampilkan halaman user dari model melalui browser, dan Controller merupakan bagian yang mengatur hubungan antara model dan view. Salah satu contoh code program yang terdapat pada modul dokumentasi ini yaitu implementasi proses controller melihat isi dokumentasi dapat dilihat pada Gambar 13. 


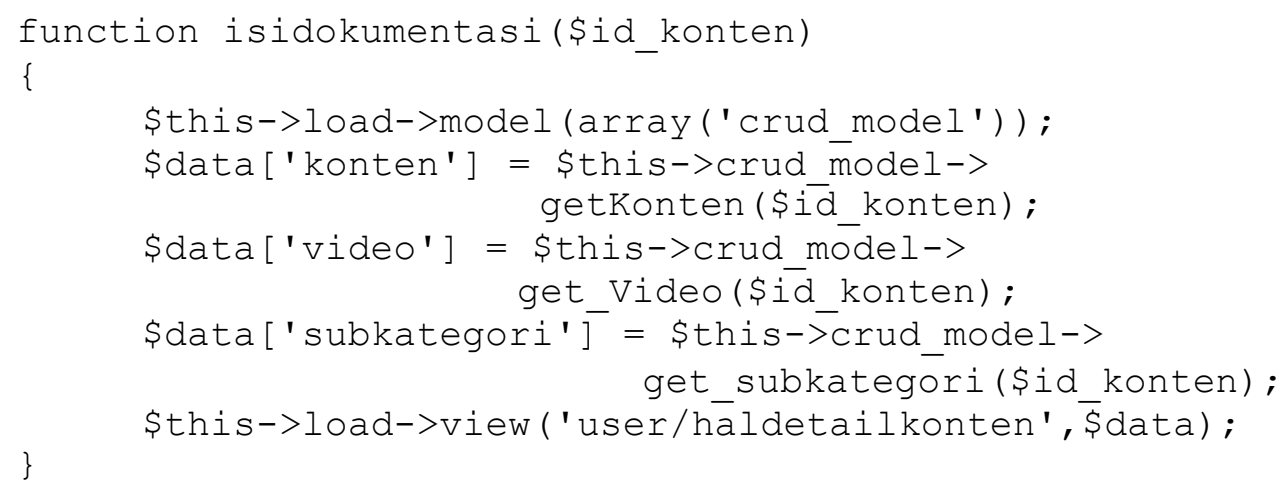

Gambar 13 Implementasi proses controller melihat isi dokumentasi

\subsection{Penyerahan Sistem dan Umpan Balik}

Tahap terakhir yaitu pengujian sistem, evaluasi, dan umpan balik. Sistem diserahkan kepada pelanggan untuk dilakukan pengujian dan evaluasi. Jika pengujian telah berhasil maka ada umpan balik yang didapat. Tahap Pembangunan Modul Dokumentasi Aplikasi POS Odoo Berbasis Web di PT Belant Persada telah selesai dibangun dan diserahkan ke Bapak Lufty Abdillah selaku pembimbing lapang. Modul dokumentasi aplikasi POS Odoo ini telah dilakukan pengujian sistem menggunakan Black box testing. Black box testing adalah pengujian sistem yang dilakukan dengan menginputkan beberapa kondisi tertentu yang sepenuhnya akan menjalankan semua kebutuhan fungsional dari sistem (Satzinger et al.2012).

Dalam pengujian sistem diperlukan dibuat sebuah skenario pengujian yang bertujuan untuk mengetahui fungsi apa saja yang sudah berhasil dibuat. Salah satu skenario pengujian untuk modul dokumentasi aplikasi POS Odoo yaitu pengujian untuk melihat dokumentasi dan pengujian untuk mengunduh file dokumentasi ditunjukan pada Tabel 2.

Tabel 3 Pengujian melihat dokumentasi dan mengunduh file dokumentasi

\begin{tabular}{|c|c|c|c|c|}
\hline Kasus Pengujian & Nilai Input & Skenario Pengujian & $\begin{array}{c}\text { Hasil yang } \\
\text { Diharapkan }\end{array}$ & Status \\
\hline $\begin{array}{l}\text { Mengunduh file } \\
\text { dokumentasi }\end{array}$ & Benar & $\begin{array}{l}\text { User mengklik tombol } \\
\text { unduh pdf }\end{array}$ & $\begin{array}{l}\text { Mengunduh file } \\
\text { dokumentasi }\end{array}$ & Berhasil \\
\hline $\begin{array}{c}\text { Melihat } \\
\text { dokumentasi }\end{array}$ & Benar & $\begin{array}{l}\text { User mengklik salah } \\
\text { satu list subkategori }\end{array}$ & $\begin{array}{l}\text { Menampilkan } \\
\text { dokumentasi } \\
\text { dari salah satu } \\
\text { subkategori } \\
\text { yang dipilih }\end{array}$ & Berhasil \\
\hline
\end{tabular}

\section{SIMPULAN}

Pembangunan Modul Dokumentasi Aplikasi Point of Sale Odoo Berbasis Web di PT Belant Persada merupakan sebuah web untuk memperkenalkan aplikasi POS Odoo kepada masyarakat dan sebagai sarana media belajar dalam 
penggunaan aplikasi POS Odoo. Modul dokumentasi aplikasi POS Odoo berisi tentang dokumentasi penggunaan aplikasi POS Odoo untuk bidang retail dan restaurant serta user dapat menguduh file dokumentasi dalam format PDF secara bebas dan menampilkan dokumentasi secara visual dalam format video. Metode yang digunakan dalam pembangunan modul dokumentasi aplikasi POS Odoo yaitu metode prototipe. Pengujian untuk modul dokumentasi aplikasi POS Odoo dilakukan dengan menggunakan Black box testing, dari hasil pengujian menyatakan bahwa semua fungsi yang dibuat sudah berhasil dijalankan sesuai dengan kebutuhan fungsi dari modul dokumentasi ini. Setelah melakukan beberapa tahapan dalam pembangunan modul dokumentasi dengan menggunakan metode prototipe dan dilakukan pengujian sistem dengan Black box testing dapat disimpulkan bahwa Pembangunan Modul Dokumentasi Aplikasi POS Odoo Berbasis Web di PT Belant Persada yang terdiri dari fitur dokumentasi, fungsi untuk mengunduh file dokumentasi, fitur beranda, fitur admin, fitur kategori, fitur subkategori, fitur konten, dan fitur unggah video berhasil dibuat berdasarkan tujuan dan kebutuhan fungsional dari website ini.

\section{SARAN}

Dalam Pembangunan Modul Dokumentasi Aplikasi POS Odoo Berbasis Web di PT Belant Persada ini masih butuh pengembangan. Oleh karena itu, agar modul dokumentasi ini lebih baik maka penulis memiliki rekomendasi untuk pengembangan selanjutnya yaitu bagian dashboard di sistem admin dapat melihat banyak pengunjung yang mengunjungi website dokumentasi supaya admin mengetahui pengunjung website ini setiap harinya dan dilakukan hosting sistem agar dapat diakses oleh masyarakat luas dan admin secara online.

\section{DAFTAR PUSTAKA}

Belant. 2019. Profile PT Belant Persada [Internet]. [diakses 2019 Mar 22]. Tersedia pada: http:/belant.net/.

Hardjono C. 2017. Perancangan dan Implementasi ERP (Enterprise Resource Planning) Modul Sales and Warehouse Management pada CV.Brada [skripsi]. Bandung (ID): Universitas Telkom.

Lestari CA. 2017. Implementasi Odoo dengan modul Accounting and Finance di SD Islam Tunas Mandiri. Jurnal Informatika Terpadu. 3(1):2-3.

Pressman RS. 2010. Software Engineering : A Practitioner's Approcach. 7th ed. New York (US): McGraw-Hill.

Sani AS, Pradana F, Rusdianto DS. 2018. Pembangunan sistem informasi point of sales terintegrasi dalam lingkup rumah makan beserta cabangnya (studi kasus: RM. Pecel Pincuk bu Tinuk). Jurnal Pengembangan Teknologi Informasi dan IImu Komputer. 2(10):3250-3251.

Satzinger JW, Jackson RB, Burd SD. 2012. System Analysis and Design in a Changing World. 6th ed. Boston (US): Cengage Learning.

Sulistiono H. 2018. Coding Mudah dengan Codelgniter, Jquery, Boostrap, dan Database. Bandung (ID): Elex Media Komputindo. 